\title{
FORECLOSURE OF CORPORATE MORTGAGES: UPDATE 1984
}

\author{
MARGUERITE J. TRUSSLER*
}

\begin{abstract}
There have been many changes to Foreclosure Law in Alberta over the past few years. In an update to a previous Alberta Law Review article (2l Alta. L. Rev. 262), the author traces the recent statutory changes to the Law of Property Act and their impact on both individuals and corporations. Several of the most recent Alberta cases are also discussed.
\end{abstract}

\section{INTRODUCTION}

The large volume of foreclosure actions in the last few years, which resulted in numerous written decisions at the level of the Masters In Chambers, have worked their way up the judicial ladder for consideration by Justices of the Court of Queen's Bench and the Court of Appeal.

Many principles have been questioned and reargued, and others have been clarified, while new ones have been enunciated for the first time. The Legislature has also responded, to a limited extent, to the results of judicial interpretation of the relevant legislation and some of the difficulties arising from the legislation which had not been tested before the current recession.

\section{LEGISLATIVE CHANGES}

\section{A. BILL 109 - REAL PROPERTY STATUTES AMENDMENT ACT, 1983 (NO. 2) ${ }^{1}$}

In 1939 the Legislature limited a mortgagee's remedy to recovery from the land. ${ }^{2}$ This provision was later modified because of the appearance of federal legislation, namely, the National Housing Act, to exclude loans made under the Act. ${ }^{3}$ In 1964 an exception was created for all mortgages given by a corporation. ${ }^{4}$

The result of the 1964 amendment was that an individual who took title to property subject to a mortgage given by a corporation did not have the protection of what are now sections 41 and 42 of the Law of Property Act. The mortgagee was not restricted to recovery from the sale of the land and the original mortgagor and subsequent transferees of the property were also liable on the covenant to pay contained in the mortgage. ${ }^{5}$

Initially lenders were reluctant to sue for judgment on the covenant against an individual, particularly in circumstances where the mortgage was a corporate residential construction mortgage assumed by the individual purchaser of the residence. When housing prices dropped so that

- B.A., LL.B. (Alberta), LL.M. (Melbourne) Partner with the firm of Parlee, Edmonton.

1. Law of Property Act, R.S.A. 1980, c. L-8, as am. S.A. 1983 (1st session), c. 97.

2. S.A. 1939, c.85, s.2.

3. S.A. 1945, c.6.

4. S.A. 1964, c.40, s.4.

5. Land Titles Act, R.S.A. 1980, c. L-5, s.62, Humble Investments Ltd. et al v. Therevan Development Corporation Ltd. (1982), 21 Alta. L.R. (2d) 40 (M.C.). 
the value of the land did not cover the amount outstanding, some mortgagees started to sue defaulting home owners for the deficiency. ${ }^{6}$ The Legislature responded by introducing provisions to stop actions on the covenant against home owners.

The amendment made the legislation extremely convoluted. In the final result the legislation provides that 5.41 of the Law of Property Act creates a principle to which there is an exception found in $s .43$ of that Act. The new provisions are a modification to the exception in s.43; however, there is a further delineation of this exception to the s.43 exception found in s.43.4(2).

The only way one can fully comprehend the amendments is to read the relevant sections as they are amended. They are as follows:

43 (1) Sections 41 and 42 do not apply to a proceeding for the enforcement of any provision

(a) of an agreement for sale of land to a corporation, or

(b) of a mortgage given by a corporation.

(1.1) Notwithstanding subsection (1), sections 41 and 42 apply to an action brought against an individual, as it relates to that individual, where

(a) the action is on

(i) a mortgage of land, whether legal or equitable, given by a corporation, or

(ii) an agreement for sale of land to a corporation,

made before or after the coming into force of this subsection, and

(b) the individual is

(i) a transferee of land that is subject to that mortgage, or

(ii) an assignee of a purchaser's interest under that agreement for sale of land,

whether the transfer or assignment was made before or after the coming into force of this subsection.

(1.2) Any waiver or release of the rights, benefits or protection given by subsections

(1.1) and (3) is against public policy and void.

(2) Sections 41 and 42 and subsections (1.1) and (3) of this section do not apply to a mortgage given to secure a loan under the National Housing Act, R.S.C. 1952, c. 188 or the National Housing Act, R.S.C. 1970, c. N-10.

(3) Notwithstanding subsection (1), where

(a) an individual is

(i) a transferee of land that is subject to a mortgage, whether legal or equitable, given by a corporation, or

(ii) an assignee of a purchaser's interest under an agreement for sale of land to a corporation,

and

(b) before the coming into force of this subsection

(i) an action was brought against that individual on that mortgage or agreement for sale, and

(ii) in respect of that action no order nisi, in the case of the mortgage, or no order for specific performance, in the case of the agreement for sale, has been granted,

then after the coming into force of this subsection no judgment or order shall be granted against the individual in respect of any of the covenants or damages referred to in section $41(1)(a)$ to (c), and sections 41 and 42 apply to the action as it relates to that individual.

43.1(1) In this section, "covenant for payment" means that portion of the covenant referred to in section 62(1) of the Land Titles Act that comprises one or more of the following:

(a) the covenants referred to in section $41(1)(a)$ and (b) of this Act;

(b) the obligation that relates to the damages referred to in section $41(1)$ (c) of this Act;

6. Canada Trustco Mortgage Company v. Stonewood Developments Ltd. et al, (1983) 28 Alta. L.R. (2d) 92 (M.C.); Credit Foncier Franco-Canadien v. Alico Development Corporation Ltd., unreported, 26 August 1983, Q.B. No. 8203 42416, per Quinn, (M.C.). 
(c) the indemnification of the transferor from and against the principal sum or other money secured by a mortgage.

(2) No action shall be brought against any individual who is a transferee of land that is subject to a mortgage, whether the transfer was made before or after the coming into force of this section, on the basis of

(a) the covenant for payment, or

(b) any obligation that exists at law, in equity or by agreement that is in substance the same as the covenant for payment.

(3) Any waiver or release of the rights, benefits or protection given by subsections (2) and $(5)$ is against public policy and void.

(4) This section does not apply in respect of a mortgage given to secure a loan under the National Housing Act, R.S.C. 1952, c. 188, or the National Housing Act, R.S.C. 1970, c. $\mathrm{N}-10$.

(5) Where

(a) an individual is a transferee of land that is subject to a mortgage, and

(b) before the coming into force of this section

(i) an action was brought against that individual on the basis of

(A) the covenant for payment, or

(B) any obligation that exists at law, in equity or by agreement that is in substance the same as the covenant for payment,

and

(ii) in respect of that action no judgment has been granted,

then after the coming into force of this section no judgment shall be granted against the individual in respect of any covenant or obligation referred to in clause (b).

43.2 Nothing in section $\mathbf{4 3}(1.1)$ or (3) or $\mathbf{4 3 . 1}$ limits or derogates from any remedy that a person has against

(a) a corporation, or

(b) a guarantor or other surety of

(i) a mortgage of land, or

(ii) an agreement for sale of land,

notwithstanding that the guarantor or other surety may become a transferee of that land or assignee of the agreement for sale.

43.3 For the purposes of section 62 of the Land Titles Act, when

(a) an individual is a transferee of land that is subject to a mortgage given by a corporation, and

(b) a corporation becomes a transferee of that land from that individual, the corporation referred to in clause (b) is deemed to be the transferee of the land from the last corporation to which that land was transferred prior to that individual's becoming the transferee of that land.

43.4(1) Sections 43(1.1) and (3), 43.1 and 43.3 apply only in respect of residential land and farm land.

(2) Sections $43(1.1)$ and (3), 43.1 and 43.3 do not apply to an individual that is or was a registered owner of residential land or farm land if

(a) in the case of residential land, neither that individual nor any member of his family has ever used that land as his bona fide residence at any time during which that individual is or was a registered owner of that land, or

(b) in the case of farm land, neither that individual nor any member of his family has himself ever used that land for carrying on bona fide farming operations at any time during which that individual is or was a registered owner of that land.

(3) In this section,

(a) "farm land" means land that is or was used for carrying on farming operations;

(b) "farming operations" means

(i) the planting, growing and sale of trees, shrubs or sod,

(ii) the raising or production of crops, livestock, fish, pheasants or poultry,

(iii) fur production, or

(iv) beekeeping;

(c) "member of his family" means

(i) an individual's grandparent, parent, sibling, child, niece, nephew or spouse, and

(ii) a grandparent, parent, sibling, child, niece, nephew of the individual's spouse;

(d) "parcel" means the aggregate of the one or more areas of land described in 
the certificate of title or described in a certificate of title by reference to a plan filed or registered in a land titles of fice;

(e) "registered owner" includes an individual purchasing the land under an agreement for sale;

(f) "residential land" means

(i) a parcel on which a single-family detached unit or duplex unit is located, or

(ii) a residential unit under the condominium Property Act, that is or was used as a residence.

Basically, where the mortgage was initially granted by a corporation, if the registered owner (or intervening transferee) is an individual who used the property as a bona fide residence or a bona fide farming operation, or a member of his family did, then judgment cannot be obtained on the covenant to pay in the mortgage. The amendments also provide for a leap-frogging over such a person for the purposes of $s .62$ of the Land Titles Act. They do not, however, apply where a guarantor of the mortgage takes title or to a mortgage under the National Housing Act.

It would make more sense to make amendments to $\mathrm{s} .41$ to reflect the principle that an individual is not to be liable on the covenant to pay where his home or farm is concerned, but where a business or speculative venture is concerned the mortgagee should not be restricted to recovery against the land regardless of whether the mortgagor is a corporation or an individual.

A change was also made to s.64 of the Law of Property Act so that, for example, if a guarantor is obligated to pay off the balance owing on a mortgage, then the guarantor can require the mortgage to be transferred to him rather than having it discharged. ${ }^{7}$

One other amendment to the Act constituted a clarification of $5.42 .{ }^{8}$ That section distinguished between urban land and farm land for purposes of setting a redemption period. There is, of course, land that fits neither definition: for example, rural acreages. The words "urban land" were replaced by the words "land other than farm land" so that there no longer is a hiatus between the two types of land for purposes of determining a redemption period. The new wording is also found in $\mathrm{s.45}$, the section relating to the appointment of a receiver. ${ }^{9}$

\section{B. BILL 50 - LAW OF PROPERTY AMENDMENT ACT, $1984^{10}$}

While the provisions of $s .43$ of the Law of Property Act were thought to be unfair to home owners who had assumed a corporate mortgage, there were other portions of the Act that operated to the detriment of the mortgagees or, perhaps more accurately, were insufficient to provide for circumstances that arose which were unjust to mortgagees. In particular, a scheme evolved whereby a residential property would be purchased for the sum of one dollar plus the assumption of the mortgage. The purchaser would then rent the property back to the vendor or to a third party. No payments would be made on the mortgage and the purchaser would pocket the rents until such time as the mortgagee could conclude a

7. Law of Property Act, R.S.A. 1980, C. L-8, as am. S.A. 1983 (1st Session), c.97, s.7.

8. Id., s.3.

9. Id., s.6.

10. Law of Property Act, R.S.A. 1980, c. L-8, as am. S.A. 1984 (2nd Session), c.24, s.2. 
foreclosure action. The time involved could be substantial because if the original mortgagor was an individual the provisions of 5.41 of the Law or Property Act made it mandatory to obtain a redemption period and advertise the property for sale. If the original mortgagor was an individual there was no personal recourse against the purchaser; even where the mortgagor was a corporation the purchaser was of ten a company without assets upon which to realize a judgment. Bill 50 was introduced to remedy these problems.

Initially, when these transactions started to occur it took some time for the mortgagee and its solicitors to react and to obtain, on notice, an order for a receiver of rents or a receiver/manager. However, by the time the remedial legislation was introduced it was possible to obtain an order for a receiver of rents or a receiver/manager without giving notice of the application, although some of the Masters still insisted that there be proof there was more outstanding on the property than the value of the property.

Section 42.1 was added and provides as follows:

42.1 Notwithstanding sections $41(2)$ and 42, in an action brought on a mortgage of land or on an agreement for sale of land where

(a) the land is transferred or sold, in the case of a mortgage,

(i) while the mortgage is in default, or

(ii) within 4 months before the mortgage goes into default,

(b) the purchaser's interest in the land is assigned or sold, in the case of an agreement for sale,

(i) while the agreement for sale is in default, or

(ii) within $\mathbf{4}$ months before the agreement for sale goes into default,

or

(c) the land

(i) is abandoned, or

(ii) is undeveloped land other than farm land as defined in section $43.4(3)$,

the Court may, without the land being first of fered for sale under section 41 (2), make a vesting order in the case of a mortgage or an order of cancellation in the case of an agreement for sale.

If land is transferred or sold while a mortgage thereon is in default or the mortgage goes into default within four months of transfer or sale, the court can order an immediate order of foreclosure without first having the land advertised for sale. Many mortgages were in default when purchased by so-called "dollar dealers" or went into default immediately thereafter. It is unlikely that such a person would find it profitable to hold a property for four months and make mortgage payments for that time before going into default. It is equally unprofitable to make this type of purchase if the mortgage can immediately foreclose and numerous months' rental cannot thereby be collected. Some "dollar dealers" are now purchasing property and not transferring title in an effort to avoid the legislation. The word "sold" in s.42.1 would cover this situation but sometimes there are evidentiary problems in proving a sale where there has been no transfer. The mortgagee can force a transfer under s.62(2) of the Land Titles Act."

Another interesting provision of $\mathrm{s.42.1}$ is the availability of a direct order for foreclosure, notwithstanding that the mortgagor may be an individual, where the land is abandoned or is undeveloped land that is not 
farm land as defined in the Act. "Abandonment" would cover the situation where the owner has left the province or where an owner has moved out and had utilities disconnected. There is a fine line between "abandoned" and "vacant", but the mere fact of vacancy without more is not sufficient. The provision for undeveloped land would catch the land speculator who purchased in his own name rather than through a corporate entity and thus had the protection of the Law of Property Act. There is still no liability on the covenant to pay, but at least the foreclosure can be expedited.

The legislation also facilitated the obtaining of a receiver and manager of rental property. Previously s.45 of the Law of Property Act provided only for the appointment of a receiver of rents. If the owner did not turn over the rent to the receiver, a further application could be made for an order allowing the receiver to enter into possession of the property, provided it was not farm land. The section did not cope with the realities of most situations and, in particular, problems such as the fact that there were no provisions for the payment of utilities (which the owner of the property invariably would not pay once deprived of the income from the property), the lack of power to rent the property if the present tenant vacated and, generally, the lack of any managerial powers which would allow for maintenance of the property. As a result a mortgagee would normally apply for a receiver with managerial powers under s.13(2) of the Judicature Act. ${ }^{12}$ This section gives wide discretionary powers to the court to grant or refuse an order. Divergent practices evolved, with applications under both s.45 of the Law of Property Act and s.13(2) of the Judicature Act. Some of the Masters in Chambers and Justices of the Court of Queen's Bench automatically granted a receiver of rents or a receiver/manager if there was rental property involved and the mortgage was in default. Others took the position that the mortgagee's security had to be in jeopardy before an order would be granted. ${ }^{13}$

The new section reads as follows:

45(1) Notwithstanding section 41 , after the commencement of an action on

(a) a mortgage of land other than farm land, or

(b) an agreement for sale of land other than farm land,

to enforce or protect the security or rights under the mortgage or the agreement for sale the Court may do one or both of the following:

(c) appoint with or without security, a receiver to collect rents or profits arising from the land;

(d) empower the receiver to exercise the powers of a receiver and manager.

(a) a mortgage of land or an agreement for sale referred to in subsection (1) is in default, and

(b) rents or profits are arising out of the land that is subject to the mortgage or agreement for sale,

the Court shall, on application by the mortgagee or vendor, appoint a receiver where the Court considers it just and equitable to do so.

(1.2) Notwithstanding subsections (1) and (1.1), an application to appoint a receiver may be made ex parte if

(a) in the case of a mortgage, the land is transferred or sold

(i) while the mortgage is in default, or

12. R.S.A. 1980 , c. J-1.

13. N.A. Properties Ltd. v. Ronald J. Young Professional Corporation (1982) 20 Alta. L.R. (2d) 399 (M.C.). 
or

(ii) within 4 months before the mortgage goes into default,

(b) in the case of an agreement for sale, the purchaser's interest in the land is transferred or sold

(i) while the agreement for sale is in default, or

(ii) within $\mathbf{4}$ months before the agreement for sale goes into default.

The most important change to the legislation allows for the appointment of a receiver of rents with managerial powers. As a result it will no longer be necessary to bring an application under s.13(2) of the Judicature Act. It is hoped the new section will also clarify that a receiver can be appointed where there is an action only for the arrears or for a declaration that the mortgage is a valid charge on the land and is in default, as well as a foreclosure action accelerating the balance outstanding on the mortgage.

The wording of the section does have some curious provisions. In subsection (1) it provides that the court may appoint a receiver. In subsection (1.1) it states that if the mortgage is in default and there is rental income from the land, the court shall upon application appoint a receiver where the court considers it just and equitable. Using the word "shall" along with the discretionary considerations of "just and equitable" is somewhat contradictory. It is unclear whether the mortgagee must prove than an order is just and equitable or whether the mortgagor has the obligation. While it is necessary for the court to retain discretion in the appointment of a receiver, it would have been preferable to word the section so that the onus is placed on the defaulting mortgagor to show that the appointment of a receiver is unjust and inequitable and that equity in the property is not a ground for denying the appointment of a receiver.

The new provisions also state that where the land is transferred or sold while the mortgage is in default or if it goes into default within four months, then an application for a receiver may be made ex parte. Just prior to the enactment of the section, the practice of the court became standardized so that all the Masters allowed an ex parte application where a "dollar purchase" was involved. However, the new section covers all situations where there is a sale during default or shortly thereafter.

Some housekeeping amendments were also necessary because of changes brought about by Bill 109 . The protective provisions of that legislation only extended to s.41 of the Law of Property Act and it was necessary to include s.42 as well. A further problem had arisen in that the legislation had not specified whether an owner had to prove he was eligible for the further protection, or a mortgagee had to prove the registered owner was not covered by the new sections. Some of the Masters took the position that the onus of proof was on the mortgagee but the amendment now clearly indicates that the onus of proof is to be on the individual who seeks the benefit of the protective provisions.

\section{LIABILITY ON COVENANT TO PAY}

\section{A. MIXED MORTGAGORS}

The Alberta Court of Appeal has resolved the question of the applicability of s.41 to a situation where there are co-mortgagors, at least 
one of whom is an individual. In Chateau Developments v. Steele, ${ }^{14}$ a group comprising individuals and corporations purchased land by way of an agreement for sale. The vendor maintained that the corporate purchasers were liable on the covenant to pay found in the agreement by virtue of the exception for corporate purchasers found in 5.43 of the Law of Property Act. The court found that s.43 did not apply where some of the purchasers were individuals and all purchasers had the benefit of s.41 and were not liable on the covenant to pay. This principle is equally applicable to mortgagors. ${ }^{15}$

\section{B. IMPLIED COVENANT TO PAY}

\section{Section 62(1) of the Land Titles Act reads as follows:}

In every instrument transferring land for which a certificate of title has been granted, subject to mortgage or encumbrance, there shall be implied the following covenant by the transferee both with the transferor and the mortgagee: That the transferee will pay the principal money, interest, annuity or rent charge secured by the mortgage or encumbrance, after the rate and at the time specified in the instrument creating it, and will indemnify and keep harmless the transferor from and against the principal sum or other money secured by the instrument and from and against the liability in respect of any of the covenants therein contained or under this Act implied on the part of the transferor.

Where property subject to a mortgage is transferred by the mortgagor to a subsequent purchaser, there is no contractual connection between the mortgagee and the subsequent transferee. Therefore, if it were not for s.62 of the Land Titles Act the mortgagee would have no action against subsequent purchasers from the mortgagor on the covenant to pay contained in the mortgage, unless he obtained an assignment from the mortgagor/vendor.

However, some limitations with respect to an action based on s.62 have now been clarified by the court. Where only part of the land originally covered by the mortgage is transferred there is no liability. ${ }^{16}$ For example, if a property subject to a blanket mortgage is divided into separate titles pursuant to the registration of a condominium plan and each of the units is transferred separately to a purchaser, then 5.62 does not apply. This situation must be contrasted to one where there is only one transfer, but several transferees, each of whom will be liable for the whole amount outstanding under the mortgage. ${ }^{17}$

Where a subsequent mortgagor takes title pursuant to a court order in a foreclosure action then the party taking title by this means is not liable to indemnify the prior registered owner against whom the foreclosure order was obtained. ${ }^{18}$ In Guaranty Trust v. Bailey ${ }^{19}$ Dechene J. held that

14. (1983) 27 Alta. L.R. (2d) 112, leave to appeal to S.C.C. refused.

15. Robinson v. Carpenter, unreported, 27 May 1982, Q.B. No. 8103 36291, per Funduk, (M.C.).

16. Montreal Trust Co. v. Boggs (1915) 8 W.W.R. 1200; Dominion of Canada Investment Co. v. Carstens, [1917] 3 W.W.R. 153, (Sask. C.A.); In re Macdonald Estate [1925] I W.W.R. 1031 (Alta. S.C.A.D.); Yorkshire Trust Co. v. Donsdale Holdings Ltd. (1983) 46 A.R. 47 (M.C.).

17. Trusts \& Guarantee Co. v. Monk (1924) 21 Alta. L.R. 151 (Alta. S.C. App. Div.).

18. Joycev. Deslauriers (1982) 26 Alta. L.R. (2d) 326, (Alta. C.A.).

19. (1984) 31 Alta. L.R. (2d) 182 (Alta. Q.B.). 
a defendant who has taken title from a party who became the registered owner as a result of a foreclosure action is not liable under s.62. This decision is presently under appeal.

\section{NATIONAL HOUSING ACT MORTGAGES}

Section 43 of the Law of Property Act provides that mortgages made pursuant to the National Housing Act are not subject to Sections 41 and 42 of the Law of Property Act. In these instances it does not matter if the mortgagor is a person or a corporation. In both cases it is possible to obtain a judgment on the covenant to pay in the mortgage. ${ }^{20}$

\section{EXECUTION ON JUDGMENT ON COVENANT TO PAY}

In 1919 the Legislature provided that it was necessary to realize against the land prior to executing on a judgment on the covenant to pay contained in a mortgage or in an agreement for sale. ${ }^{21}$ In 1920 the section as it related to mortgages was transferred to the Judicature Act. ${ }^{22}$ This provision of the Judicature Act was dropped in the 1942 revisions to the Statutes of Alberta although the similar section in the Land Titles Act referring to agreements for sale remained..$^{23}$

The Alberta Appellate Division in Credit Foncier Franco-Canadien v. Edmonton Airport Hotel Co. Ltd. and Superstein ${ }^{24}$ granted judgment on a guarantee but stayed execution on it until after the land was sold. Thereafter the courts below proceeded on the basis that a stay should be granted in all cases.

In Roynat Inc. v. 217678 Holdings Ltd., ${ }^{25}$ Master Funduk came to the conclusion that the legislation in force did not require an automatic stay of execution on a judgment against a guarantor and each case was dependent on the jurisdiction of the court to exercise a discretion under s. 18 of the Judicature Act. The Court of Appeal in both Meridian Developments Ltd. v. Nu-West Group Ltd. ${ }^{26}$ and Canada Permanent Trust Company v. King Art Developments Ltd. (No. 2) ${ }^{27}$ decided that the Superstein case did not lay down a rule that a stay of execution must be granted and that as a general rule a mortgagee may enforce the debt owing in the order the mortgagee chooses.

A judgment may only be stayed pursuant to 5.18 of the Judicature Act when the court finds it just and convenient to do so. ${ }^{28}$ In many instances there will be no grounds for the court to grant a stay. One example where

20. Maritime Life Assurance Company v. Dyjak, unreported, 24 May 1984, Q.B. No. 8303 28256, per Funduk, M.C.; defendant allowed to file amended statement of defence as per decision of Veit J., 31 August 1984, to allege mortgage not N.H.A. mortgage.

21. An Act to amend The Land Titles Act, S.A. 1919, c.37, s.1.

22. An Act to amend The Judicature Ordinance, The Judicature Act and the Land Titles Act, S.A. 1920, c.3, ss.5,6.

23. The Revised Statutes Act, 1942, S.A. 1942, c.3, s.3(i)(ii).

24. (1964) 48 W.W.R. 641 (Alta. S.C. App. Div.).

25. (1982) 23 Alta. L.R. (2d) 33 (M.C.).

26. [1984] 4 W.W.R. 97; (1984) 31 Alta. L.R. (2d) 1 (Alta. C.A.).

27. [1984] 4 W.W.R. 587; (1984) 32 Alta. L.R. (2d) l (Alta. C.A.).

28. Humble Investments Ltd. v. Therevan Development Corporation Lid. (1982) 21 Alta. L.R. (2d) 40 (M.C.). 
the court in some circumstances might consider a stay is where judgment is obtained against a guarantor whose guarantee was obtained at the time the mortgage was executed and the property has since been transferred to another party with the guarantor having no control over the default and the mortgagee is proceeding concurrently against the land.

\section{CANADA PERMANENT TRUST COMPANYv. KING ART DEVELOPMENTS LTD. (NO. 2) ${ }^{29}$}

Of particular significance in recent developments in foreclosure law and practice is the decision of the Court of Appeal in Canada Permanent Trust Company v. King Art Developments Ltd. (No. 2). In argument, counsel for the guarantors questioned the validity of decisions dating back to the 1920's. In the end result, the court opted "not to change the rules in the course of the game". However, the court was not unanimous in its decision, with Moir J.A. dissenting from the judgments of Laycraft J.A. and McGillivray C.J.A.

The majority judgment was written by Laycraft J.A. and in it he discussed four issues. The first and most important issue centred around whether or not a mortgagee who has purchased the land has, in effect, foreclosed the land and by virtue of s.44(1) of the Law of Property Act is barred from recovery of any deficiency.

Section 44(1) of the Law of Property Act reads as follows:

The effect of an order of foreclosure of a mortgage or encumbrance is to vest the title of the land affected thereby in the mortgagee or encumbrancee free from all right and equity of redemption on the part of the owner, mortgagor or encumbrancer or any person claiming through or under him subsequently to the mortgagee or encumbrancee, and

(a) the order operates as full satisfaction of the debt secured by the mortgage or encumbrancer, and

(b) the mortgagee or encumbrancee shall be deemed a transferee of the land and becomes the owner thereof and is entitled to receive a certificate of title for it.

Mr. Justice Laycraft found there was a difference between a mortgagee foreclosing land and purchasing it. The Supreme Court of Canada in 1918 in Douglas v. Mutual Life Assurance Co. ${ }^{30}$ decided that an action on the covenant could still be accomplished after a final order for foreclosure. The Alberta Legislature reacted with what is now s.44(1) of the Law of Property Act and made it clear that a mortgage debt is satisfied on foreclosure. However, Mr. Justice Laycraft found that the Alberta Legislature, unlike the Manitoba Legislature which enacted legislation that covers taking title by foreclosure or otherwise, had not specified that the same result applied where a mortgagee acquired title by sale to itself. Therefore, where title has been acquired by sale, the mortgagee may pursue any deficiency. This conclusion follows from the effect of the decisions in Security Trust Company v. Sayre ${ }^{31}$ and Gordon Grant Co. v. F.L. Boos. ${ }^{32}$

29. [1984] 4 W.W.R. 587, (1984) 32 Alta. L.R. (2d) 1 (Alta. C.A.).

30. [1918] 3 W.W.R. 529 (S.C.C.).

31. [1919] 3 W.W.R. 634 (Alta. S.C. App. Div.); [1920] 3 W.W.R. 469 (S.C.C.).

32. [1926] A.C. 781 (J.C.P.C.). 
The second issue revolved around whether a mortgagee could tender in a judicial sale, or purchase the property after an abortive sale by making a proposal to the Court. This latter procedure was that set out in Trust \& Guarantee Company v. Rice. ${ }^{33}$ The Court found that the circumstances of each case should dictate the procedure. Certain cases were appropriate for the mortgagee to tender on the property. Other cases lent themselves to a proposal by the plaintiff. One surprising variation suggested by the Court was that there might be situations where a call for tenders would be a waste of time and a mortgagee could apply directly for a sale to itself without the property being of fered for sale. ${ }^{34}$ The direct Rice order does not fit within the philosophy expressed in the Rice decision but they are becoming more common. ${ }^{35}$ The Court also felt the tender system was often not suitable for the sale of commercial and large non-commercial properties. It was made clear that there were circumstances in which the best procedure would be to list the property for sale with a real estate agent for a period of time. ${ }^{36}$ Judicial listings of 60 or 90 days have become prevalent in Master's Chambers in Edmonton. They are used even for single family residential property although it is respectfully suggested that is not what was in the contemplation of the court in King Art.

The Court also encouraged flexibility in fixing the terms upon which tenders are invited. In his decision Mr. Justice Laycraft clearly emphasized that the sale procedure was not set in stone and the Masters were free to exercise their discretion according to the needs of each case.

The decision also discussed what values should be used in foreclosure actions. Unfortunately, the Court did not provide as clear-cut directions to the appraisal community as had been hoped, particularly in the area of definitions. Moreover, a statement as to the value at which a mortgagee could purchase was not forthcoming. Prior to the decision, the Court in Edmonton had been using "forced sale on terms", with the exception of McDonald, J. in Fuhr v. Madison Development Corporation Ltd., ${ }^{37}$ while in Calgary both "forced sale on terms" and "forced sale for cash" were used. The result of the decision is that each case is dependent on its own circumstances, but whatever definitions are used they must be clearly explained by the appraiser. As a result, uncertainty is created by this part of the judgment.

The third area discussed by the Court was the issue of a stay on a judgment on a covenant in a mortgage or against a guarantor until the land had been sold. This matter has already been canvassed in Part IV, "Execution on Judgment on Covenant To Pay', of this article.

33. [1924] 2 W.W.R. 691 (Alta. S.C. App. Div.).

34. See also Central Trust Company v. Stewart Brown Real Estate Ltd., (1984) 32 Alta. L.R. (2d) 75 (C.A.).

35. For example, direct sales have been ordered in cases of dollar sales, also in Maritime Life Assurance Company v. Patterson Developments Lid., unreported, 8 August 1984, Q.B. No. 840311719 (M.C.), where guarantor had filed proposal in bankruptcy and Principal Savings and Trust Company v. 269785 Alberta Ltd., unreported, 8 August 1984, Q.B. No. 840316588 (M.C.), where property abandoned and fire damaged and guarantors had filed petition in bankruptcy.

36. See recent decision of Master Funduk in North West Trust Company v. Lichfield Investments Ltd., unreported, 7 September 1984, Q.B. No. 840317194 (M.C.).

37. [1984] 3 W.W.R. 334 (Alta. Q.B.). 
Finally, the Court considered whether a mortgagor could, in the mortgage document, contract out of s.13 of the Interest Act and agree to pay interest on a judgment at the mortgage rate rather than the statutory $5 \%$. It was decided that contracting out was not possible. The British Columbia line of cases $^{38}$ was followed rather than the Manitoba position. ${ }^{39}$ This aspect of the decision leaves many unanswered questions. The question of interest on the judgment on the "in personam" judgment causes no great difficulty. If judgment on the covenant is obtained at the order nisi stage, the rate of interest thereon accordingly drops to $5 \%$. The area of concern is in the "in rem" judgment. The order nisi is a judgment, and taken to its logical conclusion the decision in King Art would mean the interest on the order nisi would drop to 5\%. However, traditionally interest has run at the mortgage rate on the order nisi, both for purposes of the mortgagor redeeming and for calculating the balance owing for an application for final order for foreclosure, accepting a tender, or a sale to the plaintiff. 40

If the interest on the "in rem" judgment does not drop but interest on the "in personam" one does, at the final order stage two different amounts could be owing. Some inconvenience may arise in calculating two sets of figures and care must be taken to credit the "in personam" judgment with any sale proceeds as well as the "in rem" judgment. However, this situation has always prevailed with mortgages that did not have a clause allowing interest after judgment at the mortgage rate, and has presented few difficulties. This problem of interest on the order nisi requires further consideration by the Court of Appeal.

Chief Justice McGillivray, in concurring with Laycraft J.A., went on to say that there was an obligation for the court below to obtain a fair price for the land, leaving the court a wide discretion, albeit subject to review by the Court of Appeal, to use the best possible means to achieve that end. Indeed, all three judgments allow the court to be innovative in attempting to procure the best possible price for the land.

Mr. Justice Moir showed a preference for the Australian line of cases, ${ }^{41}$ and, in his dissenting judgment, found that a mortgagee could not take the land by sale and retain a deficiency judgment. He equated a sale to the plaintiff or a plaintiff successfully tendering at sale with a final order for foreclosure and satisfaction of the debt. He further found there was no jurisdiction in the court to make a sale to the plaintiff based on a proposal put before the court, but that all sales should be by tender to the Clerk of the Court. He also did an analysis of the problems presently existing in the tender system and how the system mitigates against bids being made on property.

38. Edelweiss Credit Union v. Boehm (1978) 8 B.C.L.R. 51 (B.C.S.C.), Norfolk Trust v. Wolcoski[1982] 6 W.W.R. 189 (B.C.C.A.).

39. Chin Si-Thoov. Berry [1978] 2 W.W.R. 641 (Man. Q.B.).

40. Heller-Natofin (Western) Ltd. v. Carleton Development Ltd. [1980] 1 W.W.R. 657, (B.C.S.C.).

41. Fink v. Robertson (1907) 4 C.L.R. 864 (H.C.); Simpson v. Forrester \& Others (1972-73) 132 C.L.R. 499 (H.C.). 


\section{ASSIGNMENT OF RENTS}

The provisions of Bill 50 relating to receiver managers and three recent decisions on the exercise of assignment of rents have called into question the wisdom of exercising an assignment of rents.

In Unican Development Corporation Limited v. Settlers Savings and Mortgage Corporation, ${ }^{42}$ Lutz J. found that the mortgagee who had served an assignment of rent on the tenants of an apartment complex had become a mortgagee in possession. The Court found that the mortgagee exercised and assumed full authority over the property (despite protestations that its involvement went no further than the exercise of the assignment) and frustrated the mortgagor from managing the property or obtaining information on the property in order to sell it. The mortgagee's involvement included employment of resident caretakers, collecting rents, making mortgage payments, paying utilities, securing and evicting tenants, entering into contracts for services to the building, attending tenants' needs, performing minor repairs and installing replacement locks. The Court found that the property was not properly managed and awarded the plaintiff/mortgagor damages for loss of income for rentals and the loss of value of the building.

If a mortgagee merely exercises an assignment of rents, doing nothing more than collecting the rents, it almost always follows that the mortgagor stops paying utilities, taxes and maintenance. This situation leaves the building in a precarious situation with a high likelihood that tenants will be lost. On the other hand, if a mortgagee takes it upon itself to go farther and do those minimal items necessary to keep the building functioning, it will, on the basis of this decision, be a mortgagee in possession and liable to account to the mortgagor. The risks to the mortgagee are substantial.

The other two decisions relate to the ef fectiveness of an assignment of rents. In Canada Trustco Mortgage Company v. Skoretz ${ }^{43}$ Miller J. held that an assignment of rent was not an interest in land and was not caveatable. As a result it is enforceable as a matter of contract with the original mortgagor, but is not binding on subsequent transferees of the property.

The Court of Appeal in Bank of Montreal v. Unit Liner Western Ltd. et al $^{44}$ decided that a mere assignee of rents lacks the capacity to distrain for rent if there has been non-payment in response to the exercise of an assignment of rents.

As a result of these decisions the effectiveness of an assignment, particularly against subsequent purchasers from the assignor/ mortgagor, has been seriously curtailed and the risks involved substantially increased.

42. (1984) 30 Alta. L.R. (2d) 66 (Alta. Q.B.).

43. (1983) 26 Alta. L.R. (2d) 60 (Alta. Q.B.).

44. Unreported, 29 June 1984, Appeal No. 17298. 